Studi Kasus

\title{
Perancangan Model Bisnis Pembayaran Non Tunai untuk Pengelolaan Transaksi Jasa Laundry Pada Tiara Laundry Padang
}

\author{
Ricky Akbar ${ }^{a *}$, Meza Silvana ${ }^{b}$, Afdhal Zikri ${ }^{c}$ \\ a,b,c Jurusan Sistem Informasi Fakultas Teknologi Informasi Universitas Andalas
}

\section{INFORMASI ARTIKEL}

Sejarah Artikel:

Diterima Redaksi: 01 April 2019

Revisi Akhir: 06 Januari 2020

Diterbitkan Online: 15 Januari 2020

\section{KATA KUNCI}

Pembayaran Non Tunai,

Mobile dan Web Application

KORESPONDENSI

E-mail: ricky@fti.unand.ac.id*

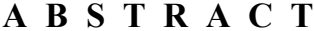

Saat ini model bisnis yang terjadi pada Tiara Laundry masih dilakukan secara manual dengan menggunakan kertas dalam melakukan pencatatan transaksi. Sebagai usaha laundry yang terus berkembang, proses transaksi yang masih manual ini menimbulkan berbagai permasalahan, seperti menumpuknya arsip transaksi laundry yang membuat Tiara Laundry kesusahan dalam hal perekapan data transaksi, serta lambatnya aliran informasi seringkali membuat Tiara Laundry tidak optimal dalam melaksanakan operasionalnya, termasuk dalam hal bertransaksi. Untuk itu dilakukan penelitian ini dengan tujuan membangun sebuah model bisnis pembayaran non tunai dalam melakukan pengelolaan transaksi Jasa Laundry. Pengelolaan data transaksi melalui penerapan transaksi pembayaran non tunai ini memanfaatkan teknologi QR Code yang merupakan salah satu solusi untuk dijadikan jawaban dalam permasalahan tersebut. Pemanfaatan teknologi QR Code dapat membuat proses pembayaran untuk transaksi jasa laundry lebih cepat, efisien dan nyaman. Metodologi penelitian yang digunakan dalam merancang model bisnis ini adalah studi literatur sebagai landasan teori, pengumpulan data berupa observasi dan wawancara, serta menggunakan metode pengembangan sistem waterfall. Adapun hasil yang didapatkan dari penelitian ini adalah usulan dari model bisnis yang baru dan sebuah aplikasi pembayaran non tunai untuk pengelolaan transaksi jasa laundry dalam membantu dan mempermudah kegiatan operasional pada Tiara Laundry.
\end{abstract}

\section{PENDAHULUAN}

Indonesia memiliki potensi pengembangan instrumen sistem pembayaran non tunai yang sangat besar[1]. Adanya peningkatan penggunaan alat pembayaran elektronik yang signifikan dalam beberapa tahun terakhir, adanya kemudahan dalam penggunaan dan pengembangan teknologi, kecenderungan dan tuntutan masyarakat untuk bertransaksi dengan menggunakan instrumen yang lebih efisien dan aman, serta beberapa keunggulan instrumen non tunai dibandingkan dengan penggunaan uang tunai, telah mendorong berkembangnya sistem pembayaran non tunai pada dunia usaha, baik itu usaha besar maupun usaha menengah dan kecil seperti usaha jasa laundry[2].

Tiara Laundry merupakan salah satu usaha jasa laundry yang cukup besar di kota Padang. Dari hasil pengamatan dan wawancara, dengan dua outlet yang telah dimilikinya, Tiara Laundry mampu menerima pesanan jasa laundry rata-rata 20-40 transaksi per bulannya. Salah satu keunikan Tiara Laundry adalah adanya sistem deposit yang diberikan kepada member yang telah terdaftar di Tiara Laundry, dengan sistem deposit ini, member akan mendapat kemudahan dalam hal pembayaran jasa laundry saat bertransaksi di Tiara Laundry, namun penerapan sistem deposit ini seringkali membuat repot karyawan/pemilik laundry, terutama dalam hal pengontrolan sisa deposit setiap member, hal ini terjadi karena mekanisme sistem yang belum baik. Tiara Laundry dalam melaksanakan kegiatan operasionalnya, termasuk dalam hal transaksi masih menggunakan sistem manual yang belum terkomputerisasi. Akibatnya kemungkinan akan terjadinya error dalam kegiatan operasional dan transaksi rawan terjadi, selain itu, transaksi pada usaha laundry yang nilainya kecil seringkali membuat karyawan laundry kesulitan dalam pengembalian uang pembayaran dari pelanggan.

Oleh sebab itu untuk mengatasi permasalahan yang telah disebutkan sebelumnya, maka perlu dirancang sebuah model bisnis baru yang 
dapat membantu mengatasi berbagai permasalahan tersebut dan juga dengan membangun sebuah aplikasi pembayaran non tunai untuk pengelolaan transaksi jasa laundry yang mampu memudahkan karyawan dalam melaksanakan operasional jasa laundry dan memudahkan customer dalam bertransaksi. Aplikasi pembayaran non tunai ini dibangun dengan memanfaatkan teknologi $Q R$ Code. QR Code atau Quick Response Code adalah image dua dimensi yang merepresentasikan suatu data, terutama data berbentuk teks[3]. QR Code dipilih karena memiliki beberapa keunggulan, salah satunya $Q R$ Code tahan terhadap kerusakan, sebab $Q R$ Code mampu memperbaiki kesalahan sampai dengan $30 \%$. Oleh karena itu, walaupun sebagian simbol $Q R$ Code kotor ataupun rusak, data tetap dapat disimpan dan dibaca [4]. Selain itu QR Code pada aplikasi ini nantinya juga dimanfaatkan untuk menyimpan data pelanggan dan saldo deposit untuk melakukan transaksi non tunai tersebut.

Beberapa penelitian yang dilakukan tentang perancangan sistem informasi pelayanan jasa laundry pada usaha laundry 21 Laundry Padang [9]. Pada penelitian tersebut telah dibangun sebuah aplikasi untuk mengelola transaksi laundry secara tersistem dan terekam dalam database. Penelitian telah dilakukan untuk membangun aplikasi penjualan voucher token listrik prabayar menggunakan teknologi QR Code berbasis web dan android [10]. Hasil dari penelitian ini yaitu sebuah aplikasi untuk mengelola penjualan voucher token listrik prabayar dengan memanfaatkan teknologi QR Code, sehingga pelanggan tidak perlu repot memasukkan nomor seri voucher kedalam meteran listrik, tetapi cukup dengan memindai QR Code yang telah di berikan oleh sistem. Dari kedua penelitian tersebut belum ada penelitian untuk pengelolaan Jasa Laundry dengan Pembayaran Non Tunai memafaatkan teknologi QR Code.

\section{METODE}

Metode yang digunakan untuk merancang model bisnis pembayaran non tunai ini adalah metode waterfall. Pengembangan dengan metode waterfall ini harus dilakukan secara berurutan dimana output dari tahapan sebelumnya merupakan input untuk tahap selanjutnya [17]. Kelebihan metode waterfall ini antara lain; mudah diaplikasikan, semua kebutuhan terhadap sistem dapat secara utuh, eksplisit dan benar didefenisikan diawal proyek sehingga software engineering (SE) dapat berjalan dengan baik dan tanpa masalah. Kekurangan dari metode waterfall adalah kesulitan dalam mengakomodasi perubahan setelah proses dijalani. Fase sebelumnya harus lengkap dan selesai sebelum mengerjakan fase selanjutnya [18]. Fase-fase pada pelaksanaan metode waterfall dapat dilihat pada Gambar 1.

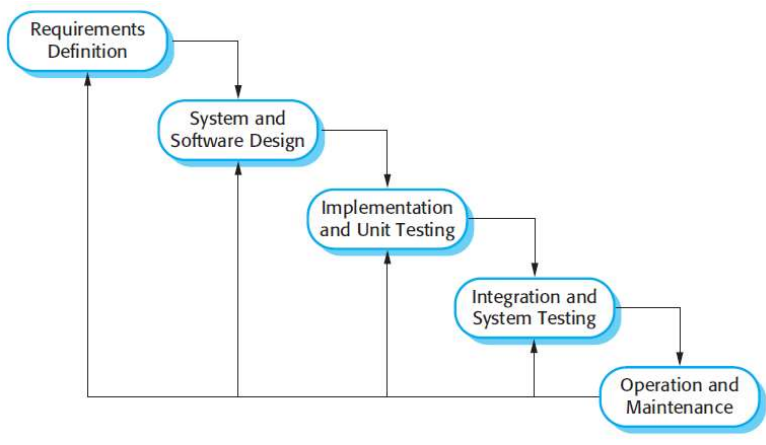

Gambar 1. Waterfall Model [19]

Dalam merancang model bisnis pembayaran non tunai untuk pengelolaan transaksi jasa laundry ini, tahapan yang dilalui hanya sampai pada tahap ketiga yaitu pada tahap Implementation and Unit Testing. Berdasarkan gambar 1 metode waterfall, dapat dijelaskan sebagai berikut :

1. Requirement Analysis and Definition

Pada tahapan ini, dilakukan analisis dan pengumpulan data yang diperlukan terhadap kebutuhan sistem dengan cara analisis dokumen, wawancara, observasi dan studi literatur yang berkaitan dengan pembangunan aplikasi pembayaran non tunai untuk transaksi jasa laundry.

2. System and Software Design

Tahap ini terdiri dari bagaimana perangkat lunak akan dibangun, dengan kata lain perencanaan solusi perangkat lunak. Data yang didapat selama tahap analisis akan diolah sehingga menjadi rancangan sistem baru dengan fungsional yang telah dirumuskan sebelumnya,. Tahapan ini berfokus pada struktur data, arsitektur perangkat lunak, rancangan basis data, dan representasi interface.

3. Implementation and Unit Testing

Dari software requirement yang dihasilkan pada tahap perancangan, maka software requirement tersebut diterjemahkan ke dalam bahasa pemrograman dalam hal ini penulis menggunakan bahasa $P H P$ untuk web base application dan Java untuk Mobile Base Application. Seteleh coding selesai dilanjutkan dengan tahap pengujian. Untuk tahapan testing akan berfokus pada Software Aplikasi dari segi logic program dan fungsional serta memastikan semua bagian sudah diuji. Hal ini dilakukan agar kesalahan atau error yang terjadi dapat di minimalisir dan memastikan output yang dihasilkan sudah sesuai dengan kebutuhan.

\section{HASIL}

Pada bagian ini dijelaskan hasil dari analisis dan perancangan dari model bisnis pembayaran non tunai untuk pengelolaan transaksi jasa laundry dengan memanfaatkan teknologi $Q R$ Code pada Tiara Laundry Padang. Analisis sistem ini menggunakan berbagai tools antara lain; Bussines Process Modelling Notation (BPMN), analisis kebutuhan fungsional sistem, diagram use case, skenario use case, diagram sequence, dan class analysis. Kemudian untunk design system terdiri dari design database, struktur table dan basis data, arsitektur aplikasi, diagram class, dan rancangan antar muka. 


\subsection{Analisis Sistem}

Analisa sistem adalah tahapan menganalisis sistem yang berjalan serta merancang sistem yang diusulkan untuk memenuhi kebutuhan fungsional yang diharapkan dari sistem yang dibangun. Analisa sistem menggunakan model UML (Unified Modelling Language). UML yang digunakan untuk analisa sistem ini adalah diagram use case, skenario use case, diagram sequence, dan class analysis.

\subsubsection{Kedudukan Sistem}

Model bisnis yang sedang berjalan pada Tiara Laundry Padang saat ini terdiri dari lima sub sistem, yaitu sistem penerimaan pesanan laundry, sistem pengembalian pesanan laundry, sistem pendaftaran member, sistem penambahan/isi ulang deposit member dan sistem pemberian upah karyawan. Pada Tiara Laundry model bisnis tersebut masih dilakukan secara manual dan belum terkomputerisasi, akibatnya aliran informasi sering berjalan lambat dan membuat operasional laundry kurang berjalan optimal. Oleh sebab itu, pada penelitian ini dirancanglah model bisnis pembayaran non tunai untuk pengelolaan transaksi jasa laundry dengan membangun sebuah aplikasi dengan platform web dan mobil memanfaatkan teknologi QR Code.

\subsubsection{Model Bisnis yang Berjalan}

Model bisnis yang berjalan pada Tiara Laundry Padang saat ini meliputi: proses penerimaan pesanan laundry, proses pengembalian pesanan laundry, proses pendaftaran member baru laundry dan proses penambahan deposit member serta proses pemberian gaji/upah karyawan di Tiara Laundry. Alur proses penerimaan pesanan laundry dapat dilihat pada Gambar 2.

Tahapan yang dilakukan untuk proses penerimaan laundry adalah sebagai berikut:

1. Pegawai/pemilik laundry menerima barang/pakaian kotor dari pelanggan.

2. Barang yang telah diterima, selanjutnya akan ditimbang untuk mengetahui berat cucian pelanggan.
3. Barang yang telah ditimbang akan dicatat ke dalam nota transaksi laundry beserta data-data lain yang diperlukan, seperti: nama pelanggan, alamat, jenis parfum yang dipilih dan lain sebagainya.

4. Selanjutnya pegawai/pemilik laundry meminta tagihan biaya jasa laundry ke pelanggan. Apabila pelanggan adalah member laundry, maka pegawai/pemilik laundry akan mengurangi jumlah deposit member yang ada sesuai dengan berat cucian, kemudian dibuatkan nota transaksi lunas dan cucian pun siap diproses oleh karyawan cuci (Washer) laundry.

5. Apabila pelanggan bukan member, maka pegawai/pemilik laundry meminta tagihan jasa laundry ke pelanggan. Jika pelanggan membayar lunas maka pegawai akan membuatkan nota transaksi lunas, namun apabila pelanggan belum membayar lunas, maka pegawai/pemilik laundry akan membuatkan nota transaksi belum lunas untuk pelanggan. Kemudian cucian akan diproses oleh karyawan cuci (washer).

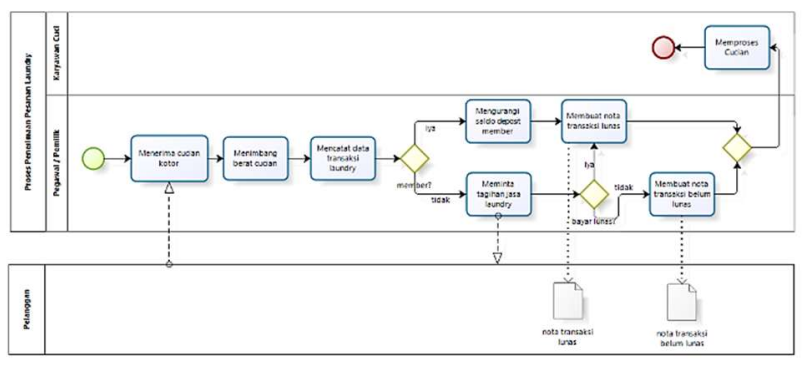

Gambar 2. BPMN Penerimaan Pesanan Laundry

\subsubsection{Model Bisnis Yang Diusulkan}

Model bisnis pengelolaan transaksi laundry usulan dapat dimodelkan menggunakan BPMN. Terdapat empat proses bisnis yang diusulkan. BPMN proses transaksi jasa laundry yang diusulkan pada perancangan model bisnis pembayaran non tunai menggunakan Teknologi $Q R$ Code dapat dilihat pada Gambar 3.

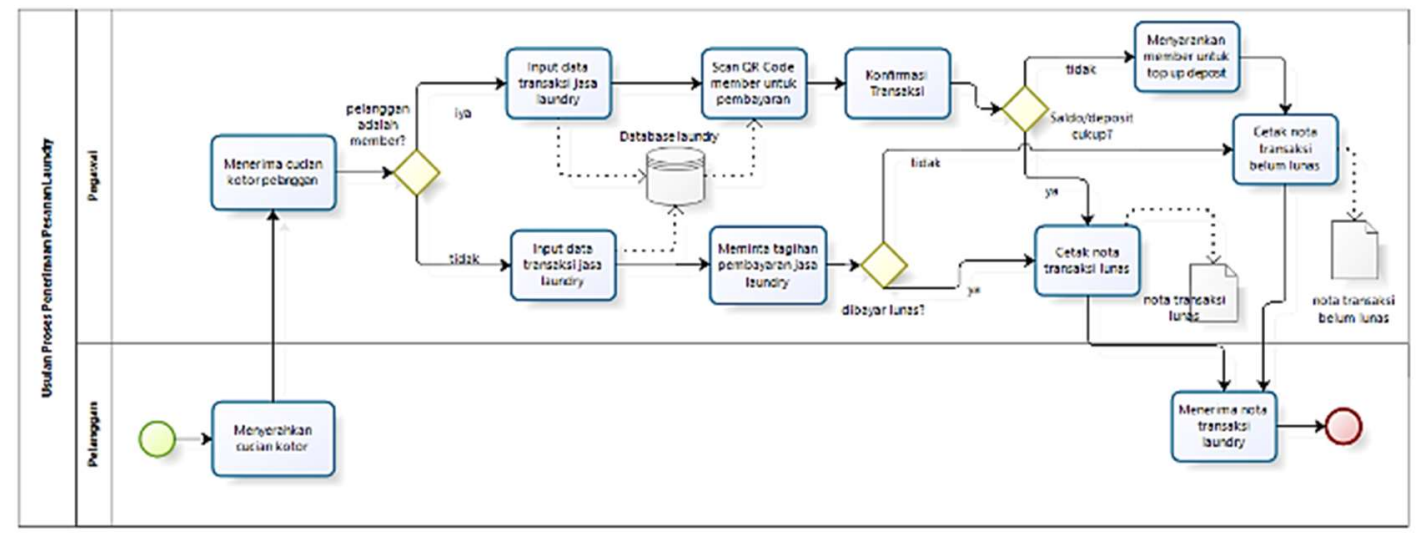

Gambar 3. BPMN Usulan Proses Transaksi Jasa laundry 
Berikut merupakan penjelasan dari gambar 4 tentang usulan model bisnis transaksi pembayaran non tunai jasa laundry pada Tiara Laundry Padang:

1. Proses diawali dengan diberikannya cucian kotor oleh pelanggan kepada pegawai di Tiara Laundry

2. Selanjutnya pegawai menerima cucian kotor pelanggan. Setelah itu pegawai akan menginputkan data transaksi laundry ke sistem

3. Untuk pelanggan yang berstatus member, pegawai meminta kartu member atau $Q R$ Code member untuk melakukan pembayaran jasa laundry.

4. Kemudian member menyerahkan kartu member atau memperlihatkan $Q R$ Code member kepada pegawai, dan selanjutnya pegawai melakukan scanning terhadap $Q R$ Code member

5. Apabila jumlah deposit member mencukupi untuk biaya transaksi yang dilakukan, maka transaksi berhasil dan pegawai akan mencetak nota transaksi yang terjadi

6. Kemudian apabila jumlah deposit member tidak mencukupi untuk biaya transaksi, maka pegawai akan menyarankan kepada member untuk melakukan isi ulang deposit member dan mencetak nota transaksi belum lunas.

7. Sedangkan untuk pelanggan yang bukan member, untuk pembayaran jasa laundry, pegawai meminta langsung uang tunai kepada pelanggan sebagai pembayaran tagihan jasa laundry.

8. Apabila pelanggan membayar lunas maka pegawai akan mencetak nota transaksi lunas, dan apabila pelanggan tidak melakukan pembayaran tagihan, maka pegawai akan mencetak nota transaksi belum lunas.

\subsubsection{Analisis Kebutuhan Fungsional}

Proses data collecting dan business model yang diusulkan menghasilkan kebutuhan fungsional. Berdasarkan hasil analisis model bisnis pengelolaan transaksi jasa laundry yang diusulkan, maka didapatkan beberapa kebutuhan fungsional, antara lain:

1. Pemilik laundry dapat mengelola data user aplikasi.

2. Pemilik laundry dapat mengelola data master laundry

3. Pemilik laundry dapat mengelola data karyawan dan member seperti mengubah, melihat dan menghapus data.

4. Pemilik laundry dapat melihat dan mencetak laporan transaksi laundry

5. Pemilik laundry dapat melihat dan mencetak laporan pengisian saldo/deposit.

6. Pemilik laundry dapat melihat rekap upah karyawan berdasarkan jasa.

7. Pegawai laundry dapat melalukan pendaftaran member baru.

8. Pegawai laundry dapat mengelola data member seperti mengubah, melihat dan menghapus data.

9. Pegawai laundry dapat mengelola data orderan laundry seperti melihat data order laundry, menambah data order, dan memperbaharui status order.

10. Pegawai laundry dapat melakukan transaksi pembayaran jasa laundry untuk member.

11. Pegawai laundry dapat melakukan pengisian deposit member
12. Pegawai laundry dapat melakukan validasi terhadap permintaan pendaftaran menjadi member dari pelanggan.

13. Pegawai laundry dapat mencetak kartu member dan nota transaksi laundry.

14. Pegawai laundry dapat melihat riwayat transaksi dan riwayat pengisian deposit member.

15. Member dapat melihat informasi tentang laundry, seperti layanan, parfum, paket-paket yang tersedia dan list harga laundry.

16. Member dapat melihat riwayat transaksi di laundry.

17. Member dapat melihat profil dan sisa deposit dan $Q R$ Code identitas member.

18. Member dapat melihat status cucian dan melihat riwayat transaksi di laundry.

19. Member dapat melakukan pendaftaran untuk menjadi member laundry.

20. Member dapat melihat $Q R$ Code identitas member

\subsubsection{Diagram Use Case Aplikasi}

Diagram Use case menggambarkan hubungan antara fungsiona dengan aktor yang terlibat di dalam sistem. Diagram use case untuk design model bisnis untuk pengelolaan transaksi jasa laundry secara non tunai dapat dilihat pada gambar 4 .

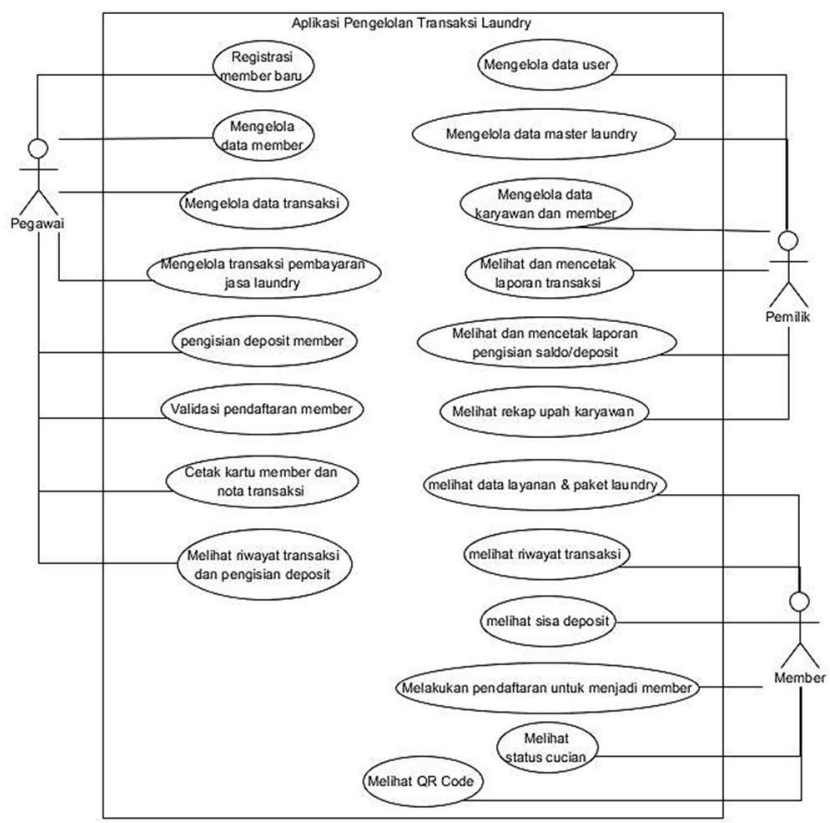

Gambar 4. Use Case Diagram Perancangan Aplikasi

\subsubsection{Skenario Use Case}

Skenario Use case digunakan untuk memaparkan tahpan-tahapan dalam penggunaan fungsional yang ada pada sistem. Salah satunya adalah Skenario use case, yang di desaign adalah registrasi member baru. Skenario use case dari registrasi member baru menggunakan aplikasi web terdapat pada tabel 1 . 
Tabel 1. Skenario Use Case Registrasi Member Baru

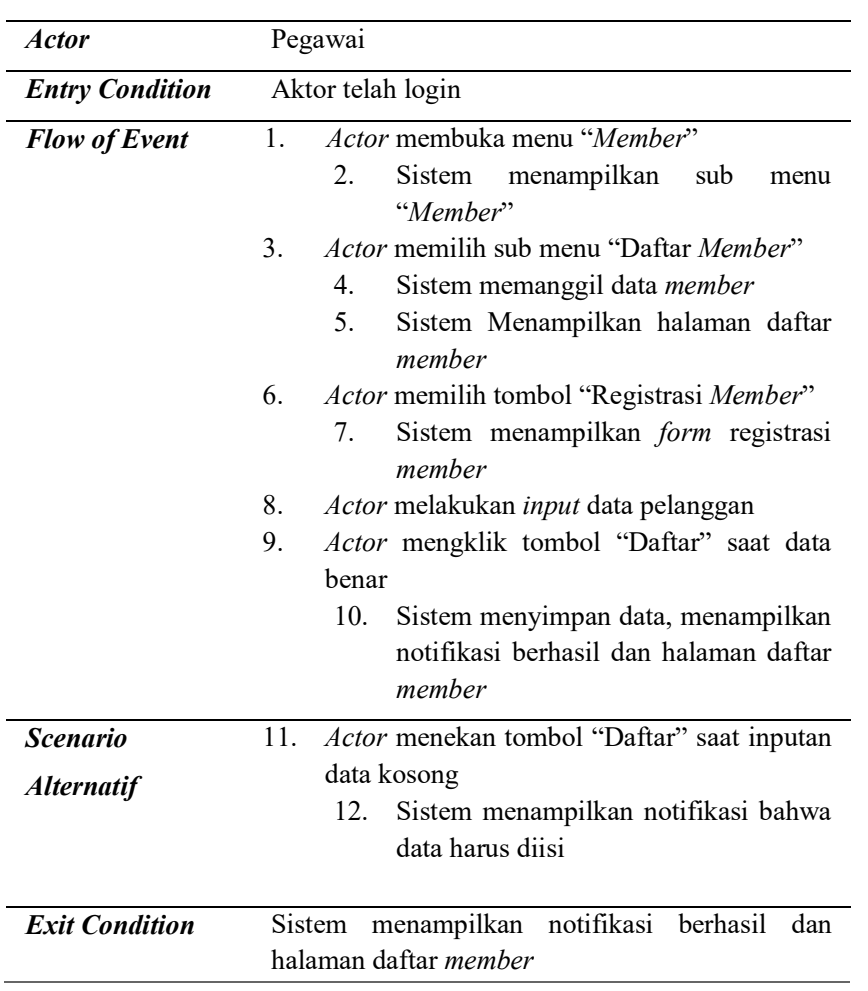

\subsubsection{Diagram Sequence}

Diagram Sequence ini berpedoman pada analisa diagram use case, dan selanjutnya dikembangkan sampai pada proses tahapan terkecil yang ada disetiap use case. Pada diagram sequence, setiap actor di asumsikan telah login terlebih dahulu sebelum masuk ke proses berikutnya. Salah satu diagram sequence yang di design adalah diagram sequence registrasi member baru melalui aplikasi web seperti pada gambar 5 .

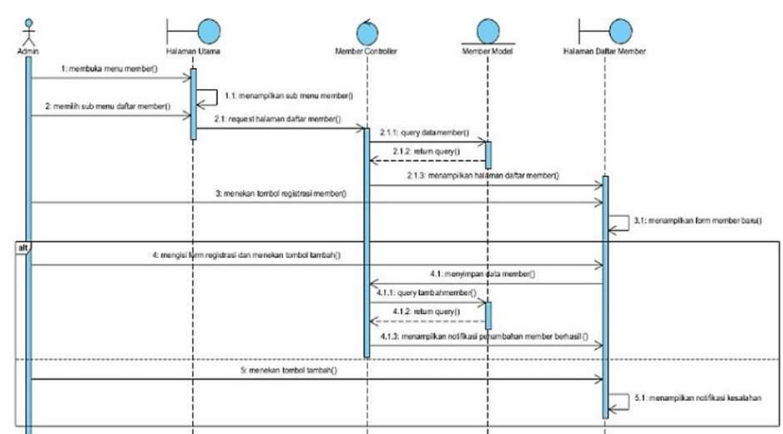

Gambar 5. Sequence Diagram Registrasi Member Melalui Web

Berdasarkan gambar 5, model bisnis registrasi member baru dapat dilakukan oleh user pegawai melalui web. Tahapan ini dimulai ketika user meng-klik menu "Member". Setelah itu sistem menampilkan sub menu member, selanjutnya user memilih sub menu "Daftar Member". Selanjutnya sistem me-request data member kepada controller dan memanggil query "datamember()" dari database. Selanjutnya controller menjalankan query dan menampilkan data member pada halaman list member. User kemudian memilih tombol "Registrasi Member" untuk memanggil form member baru. User mengisi form member baru dan menekan tombol "Tambah". Selanjutnya controller memanggil query "tambahmember()" untuk menyimpan data ke database. Terakhir sistem menampilkan notifikasi inputan data berhasil. Jika user menekan tombol "Tambah" saat inputan data salah atau kosong maka sistem menampilkan notifikasi kesalahan.

\subsubsection{Class Analysis}

Class analysis berguna untuk menjelaskan kelas-kelas yang terlibat dalam setiap bagian proses yang digambarkan berdasarkan diagram sequence. Class analysis yang di design adalah class analysis registrasi member baru melalui aplikasi web seperti pada gambar 6 .

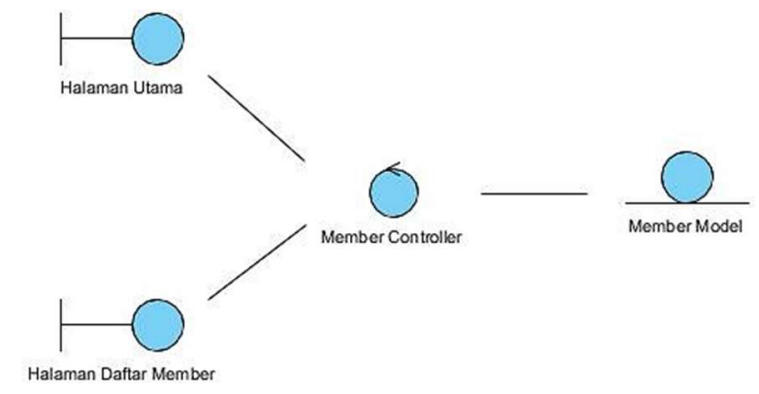

Gambar 6. Class Analysis Registrasi Member Baru

\subsection{Design Sistem}

Pada model bisnis yang ada saat ini, flow sistem dan system requirement yang dibutuhkan, diperoleh hasil yang menjadi acuan dan tolak ukur dalam melakukan design sistem. Design sistem ini meliputi Desgin dari database, struktur table dan basis data, arsitektur aplikasi, diagram class, dan design antar muka

\subsubsection{Design Database}

Design Database diawali dengan membangun struktur basis data menurut entity yang dipakai dan relasi dengan entity lainnya. Entity dan hubungan antar entity dapat digambarkan dengan ERD (Entity Relationship Diagram). Pada aplikasi ini, basis data yang di design memiliki empat belas table, table-table ini terdiri dari sebelas master table dan tiga transaction table. Master table terdiri dari tabel member, tabel karyawan, tabel order, tabel layanan, tabel paket_kiloan, tabel paket_helaian, tabel parfum, tabel status_pengerjaan, tabel barang, tabel admin dan tabel history_topup. Sedangkan transaction table terdiri dari transaksi table, tabel pekerja_transaksi dan tabel detail_cucian. Design relasi tabel dapat dilihat pada gambar 7 .

\subsubsection{Struktur Tabel dan Database}

Table structure dan Database merupakan penjabaran dari table yang ada di masing-masing relasi beserta atributnya. Status tersebut berupa primary key, foreign key, tipe data, nama atribut, dan nama tabel. Tabel 2 dibawah ini adalah rincian dari tabel member. 
Tabel 2. Tabel Member

\begin{tabular}{lll}
\hline \multicolumn{1}{c}{ Nama atribut } & \multicolumn{1}{c}{ Tipe data } & \multicolumn{1}{c}{ Keterangan } \\
\hline No_member & Integer $(10)$ & PK \\
\hline User_id & Integer $(10)$ & FK \\
\hline Nama & Varchar (30) & \\
\hline No_telp & Varchar (13) & \\
\hline Alamat & Longvarchar & \\
\hline Saldo & Float & \\
\hline reg_date & Date & \\
\hline Email & Varchar(20) & \\
\hline Password & Varchar(50) & \\
\hline
\end{tabular}

\subsubsection{Arsitektur Aplikasi}

Perancangan model bisnis pembayaran non tunai untuk pengelolaan transaksi jasa laundry pada Tiara Laundry ini menggunakan MVC arsitektur (Model View Controller) dengan Pemrograman Berbasis Objek (PBO), memakai Laravel framework untuk membangun web application dan Android Studio sebagai tool dalam membangun mobile application. Arsitektur MVC yang di design pada pembangunan aplikasi ini dapat dilihat pada gambar 8 .

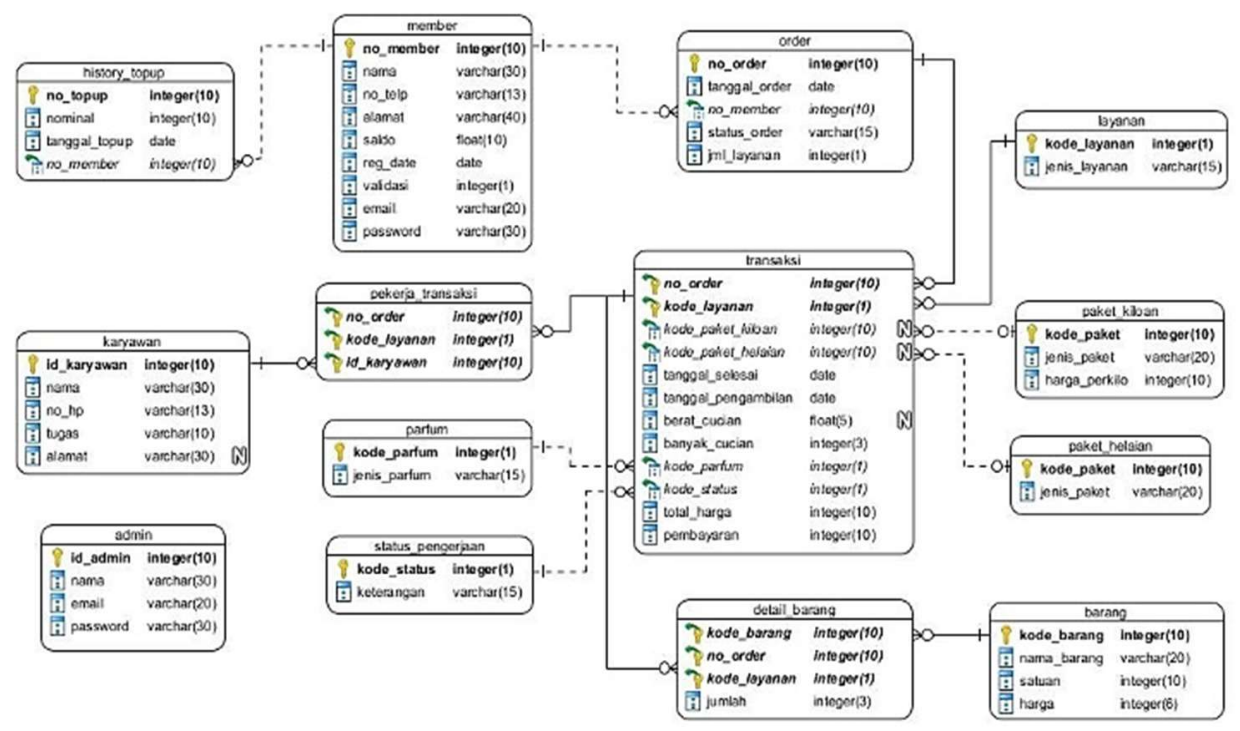

Gambar 7. Design ERD Sistem

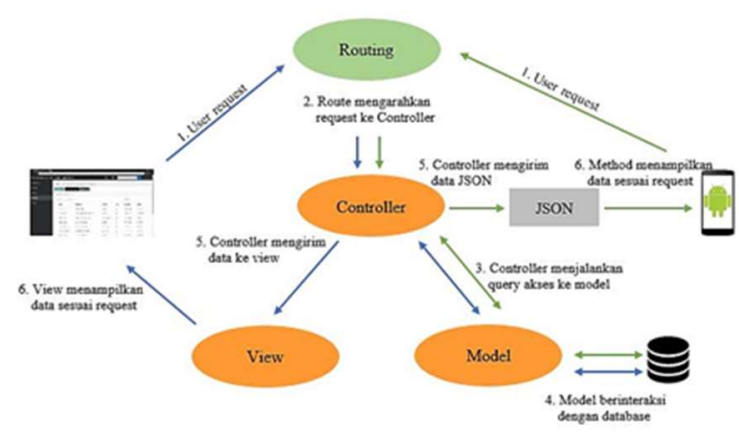

Gambar 8. Arsitektur MVC Aplikasi

Keterangan :

Alur sistem pada aplikasi web

Alur sistem pada aplikasi mobile

Berdasarkan gambar 8 mengenai arsitektur aplikasi terlihat bahwa dalam membanngun aplikasi web terdapat empat elemen penting yang terlibat, yaitu routing, controller, model, dan view. Saat user me-request sistem, routing melanjutkan kepada controller dengan method yang dibutuhkan. Kemudian Controller memanggil data melalui model. Selanjutnya model merespon dan mengambil data dari database. Data yang diperoleh oleh model dikirim kembali kepada controller untuk kemudian ditampilkan oleh view ke halaman user.

Proses pada mobile application hampir sama dengan web application tadi dimana ketika user me-request sistem, maka fungsi method dijalankan untuk mengelola perintah tersebut dan melanjutkan ke routing. Routing memanggil fungsi controller untuk meminta data menggunakan model. Model merespon dengan database dan mengirim data ke controller. Kemudian controller mengirim data berupa JSON kepada fungsi method untuk ditampilkan oleh view ke halaman user.

\subsubsection{Diagram Class}

Diagram Class adalah tahapan dalam menggambarkan struktur kelas-kelas dari suatu sistem. Dalam diagram class terdapat kelas view, model, dan controller. Diagram Class juga menampilkan semua atribut dari masing-masing kelas beserta method yang ada didalamya. Method yang ada pada masing-masing kelas mempunyai tugas tersendiri sesuai kebutuhan sistem. Diagram Class pada aplikasi ini dapat dilihat pada gambar 9. 


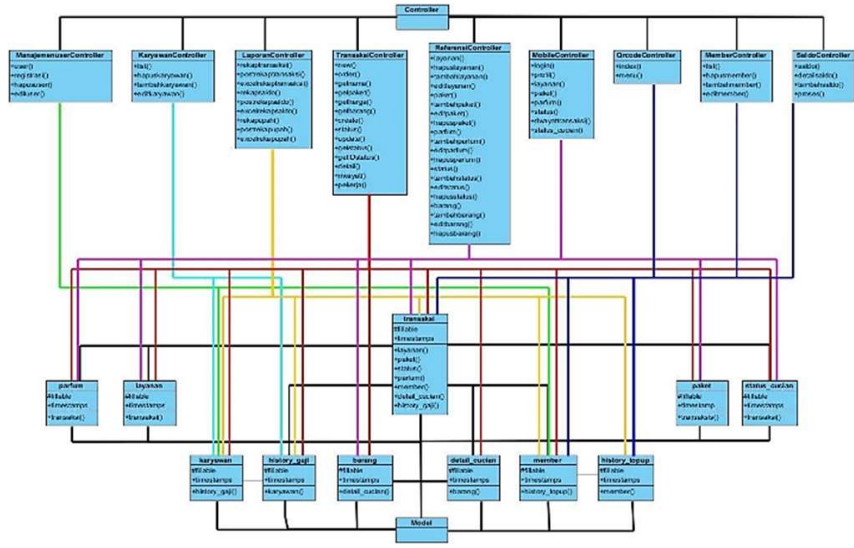

Gambar 9 Diagram Class Aplikasi

\subsubsection{Perancangan Antar Muka Aplikasi}

Antarmuka adalah proses komunikasi user dengan sistem. Antarmuka pengguna (user interface) merupakan suatu media bagi user untuk menerima dan memberikan informasi agar dapat membantu dalam penelusuran masalah hingga ditemukan solusi. Gambar 10 dibawah ini merupakan contoh dari design user interface untuk melihat riwayat transaksi jasa laundry menggunakan web application.

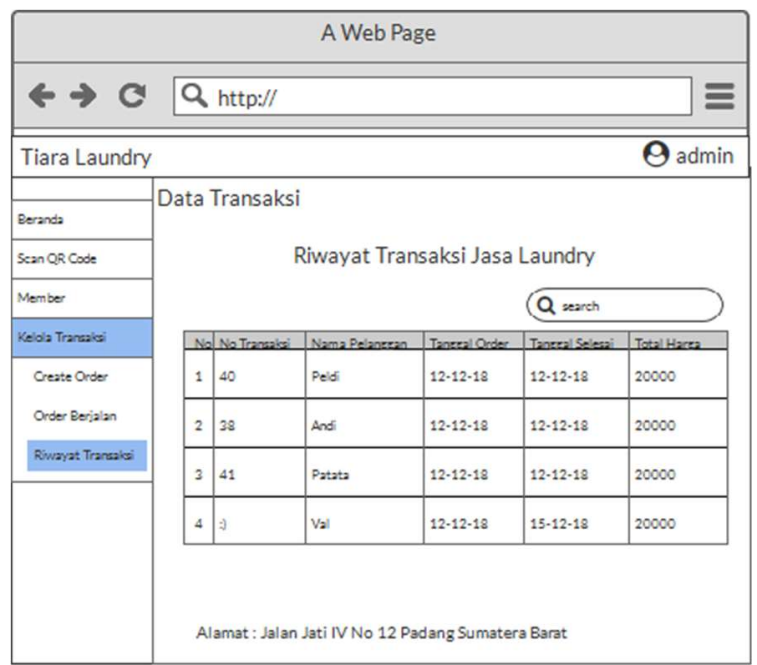

Gambar 10. Perancangan antarmuka halaman riwayat transaksi

User Interface Mobile Application yang dijelaskan pada bagian ini adalah antarmuka halaman riwayat transaksi. Perancangan antarmuka halaman tersebut dapat dilihat pada gambar 11 .

\section{PEMBAHASAN}

Bagian ini menjelaskan mengenai hasil dari rancangan yang telah di lakukan dalam bentuk implementasi sistem dan juga dilakukan pengujian terhadap sistem yang sudah dirancang. Agar diketahui nanti apakah sistem yang dibangun ini sudah sesuai dengan kebutuhan model bisnis yang di usulkan

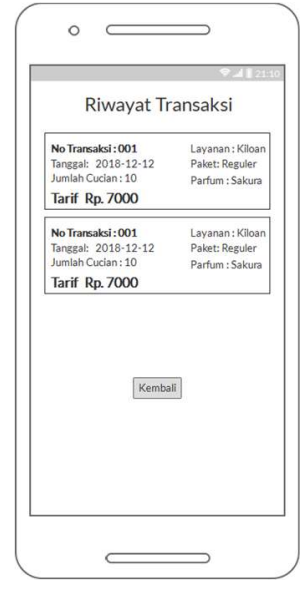

Gambar 11. Halaman Riwayat Transaksi

\subsection{Implementasi Sistem}

Model bisnis pembayaran non tunai yang di rancang ini dibantu oleh aplikasi yang dibangun sesuai dengan kebutuhan. Aplikasi untuk pengelolaan transaksi jasa laundry dengan menggunakan teknologi Quick Response (QR) Code yang difungsikan sebagai sistem untuk melakukan pengelolaan dan menyajikan data dari informasi yang berkaitan dengan pengelolaan laundry. Pada pembangunan model bisnis ini terdapat tiga aktor dan enam belas fungsional yang terlibat. Masing-masing fungsional dapat mewakili tugas dari user dan dapat memberikan efisiensi dan efektifitas terhadap semua proses pada system nantinya.

Web Application dibangun menggunakan pemrograman PHP (Pearl Hypertext Preprocessor) dan framework Laravel serta web server apache XAMPP versi 3.2.2. Sementara itu Database yang digunakan sebagai tempat penyimpanan data adalah database MySQL. Untuk Mobile Application digunakan Android Studio IDE versi 3.0. Android Studio dipilih karena memiliki keunggulan dibandingkan aplikasi pemrograman mobile lain, diantaranya karena pembangunan antar muka yang lebih mudah dan efisien, memiliki banyak library dan dapat mendukung semua perintah pengkodean mobile serta dilengkapi dengan emulator yang mendukung semua devices.

\subsubsection{Pengkodean Program}

Pada bagian ini kode program yang dijelaskan sesuai dengan arsitektur yang digunakan adalah kode untuk MemberController. Potongan kode program MemberController ini dapat dilihat pada gambar 12. 


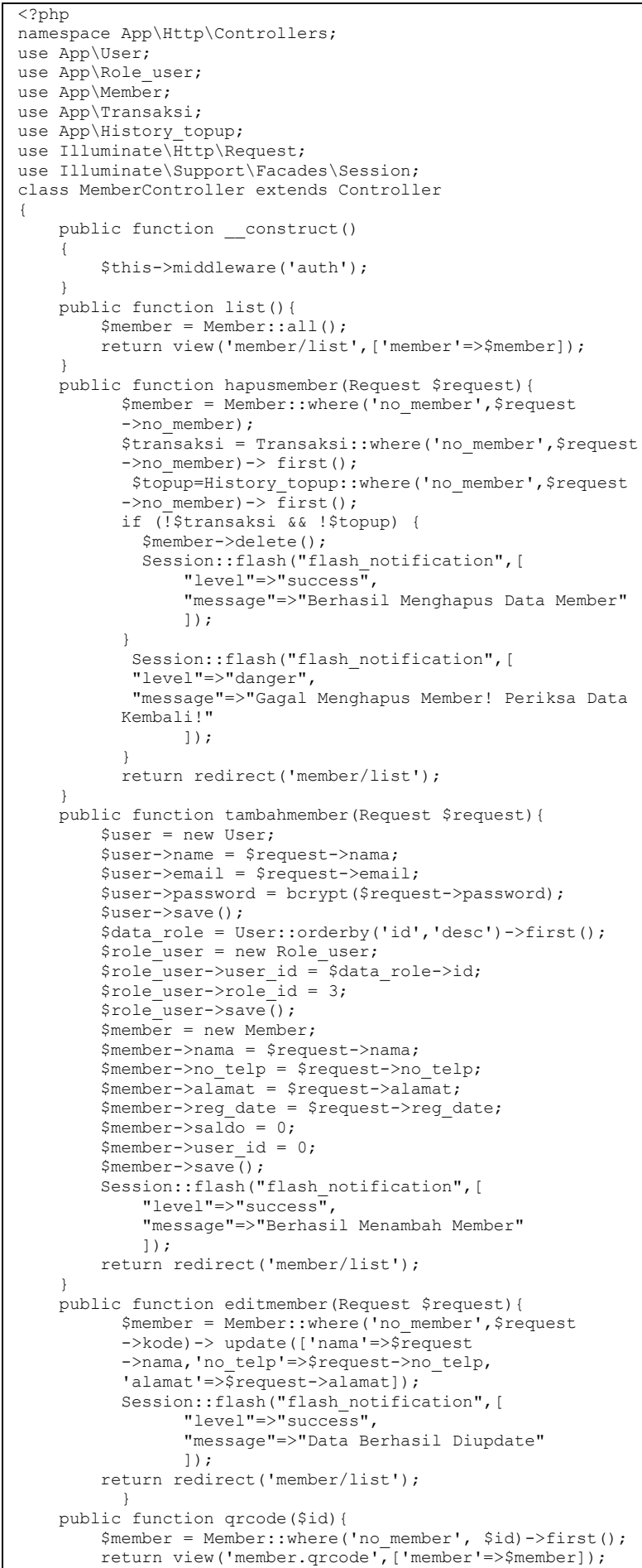

Gambar 12. Kode program MemberController

\subsubsection{Implementasi Antarmuka}

Pada bagian ini dijelaskan tampilan web application dalam perancangan model bisnis pembayaran non tunai untuk pengelolaan

transaksi jasa laundry pada Tiara Laundry. Salah satu tampilan web application dari sistem yang dibangun adalah halaman utama pemilik. Implementasi halaman utama pemilik dapat dilihat pada gambar 13.

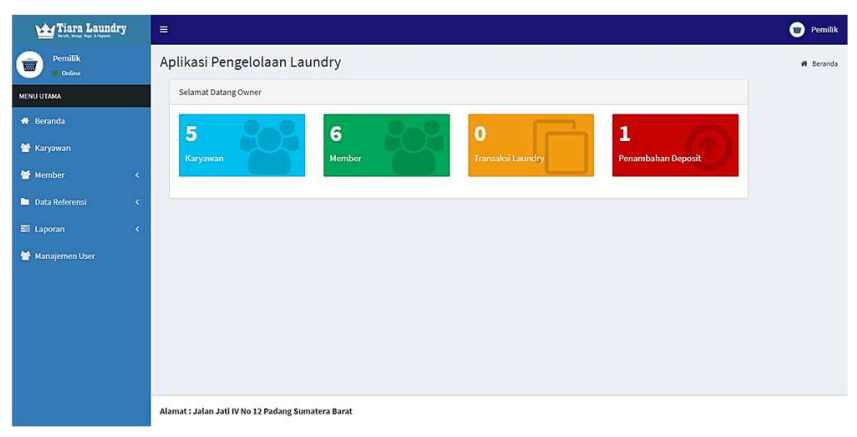

Gambar 13. Tampilan Halaman Utama Pemilik

Untuk Mobile Application yang dibangun khusus di akses nantinya oleh user menggunakan smartphone. Contoh bagian menu yang dibangun adalah halaman show QR Code. Halaman show QR Code dapat dilihat pada Gambar 14.

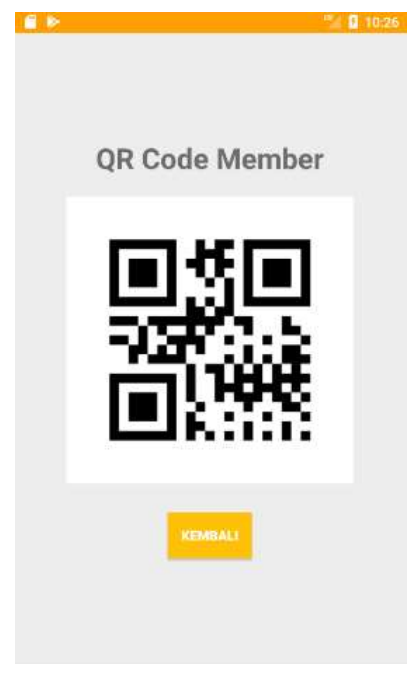

Gambar 14. Halaman QR Code

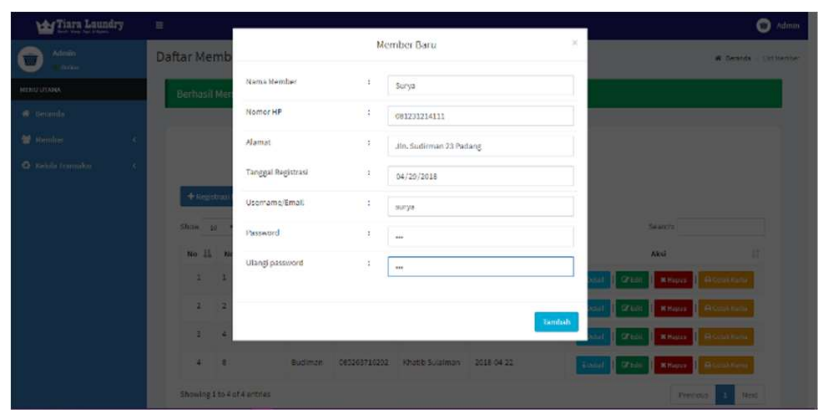

Gambar 16. Input Registrasi Member Baru (Benar) 


\subsection{Pengujian Sistem}

Tahap pengujian sistem merupakan proses untuk memeriksa apakah

aplikasi yang dihasilkan telah berjalan sesuai dengan perancangan sistem yang telah ditetapkan. Pengujian dilakukan menggunakan metode black box testing, yaitu metode pengujian yang berfokus pada pemeriksaan ketersediaan fungsional yang sudah dirancang pada aplikasi. Salah satu pengujian yang dilakukan adalah pengujian registrasi member baru melalui web. Hasil pengujian tambah data member dapat dilihat pada Gambar 15, 16, dan 17.

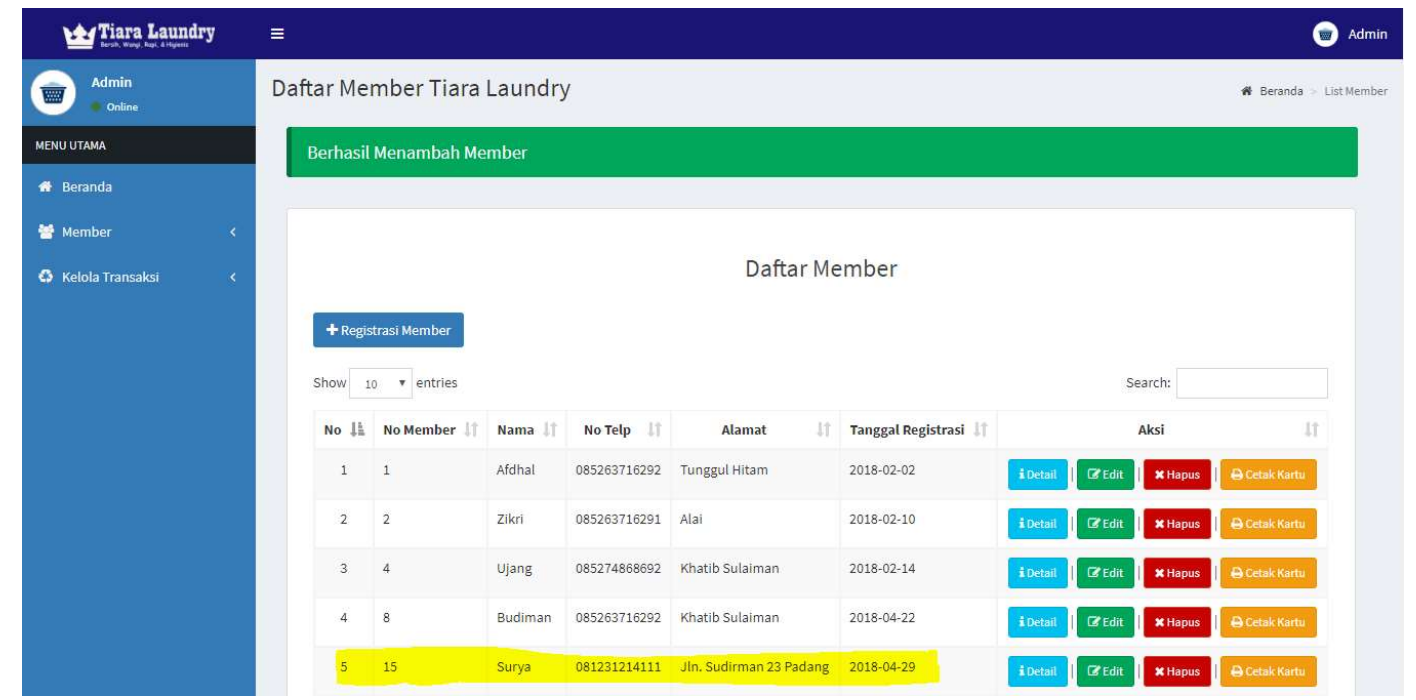

Gambar 17. Output Pengujian Registrasi Member Baru (Benar)

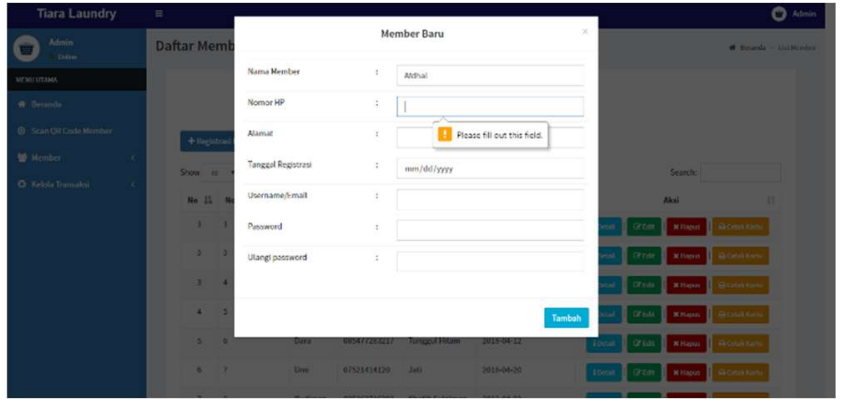

Gambar 18. Output Pengujian Registrasi Member Baru (Alternatif)

\section{KESIMPULAN}

Model bisnis pembayaran non tunai untuk pengelolaan transaksi jasa laundry dengan memanfaatkan teknologi QR Code pada Tiara Laundry Padang, telah berhasil dibangun dengan metode waterfall. Dari setiap tahap yang dilakukan dalam metode waterfall yaitu tahap analisis, design, coding, dan implementasi. Dengan telah dibangunnya aplikasi ini permasalahan terkait dengan penumpukan arsip, perekapan laporan di akhir transaksi dan sistem pembayaran yang konvensional telah dapat diatasi dimana setiap transaksi yang terjadi telah terekam didalam database, dengan begitu pihak manajemen yang memerlukan laporan transaksi bisa di cetak kapanpun dibutuhkan. Selain itu dengan metode pembayaran non tunai setiap transaksi dapat dilakukan dengan cepat dan lebih efisien.

\section{DAFTAR PUSTAKA}

[1] Hasibuan, L. 2018. Ini Alasan Orang Indonesia Mulai Tinggalkan Transaksi Tunai. [Online] Tersedia di: https://www.cnbcindonesia.com. Diakses 5 Juli 2018

[2] Sitorus, Siera Rossa. 2006. "Analisis Pengaruh Penggunaan Kartu Pembayaran Elektronik Dan Daya Substitusi Transaksi Non Tunai Elektronik Terhadap Transaksi Tunai Indonesia”. Skripsi pada Institut Pertanian Bogor. Bogor: Tidak Diterbitkan.

[3] Rahayu, Yeni Dwi, dkk. 2006. Pembuatan Aplikasi Pembacaan Quick Response Code Menggunakan Perangkat Mobile Berbasis J2ME Untuk Identifikasi Suatu Barang. Surabaya: Politeknik Elektronika Negeri Surabaya Institut Teknologi Sepuluh Nopember

[4] Pramihapsari, M. Kaldera, M. P. (2012) "Perancangan Labelling Pada Dokumen Menggunakan QR Code", Teknik Komputer, 20, pp. 59-67.

[5] Bank Indonesia. 2013. Sistem Pembayaran. http://www.bi.go.id/id/sistempembayaran/Contents/Default.aspx. Diakses tanggal 15 Desember 2017

[6] Surat Edaran (SE) Menteri Dalam Negeri Nomor 910/1866/SJ. 2017. Tentang Implementasi Transaksi Non Tunai.

[7] Suprayogi, Dwi Aries \& Mahmudy, Wayan F. 2014. "Penerapan Algoritma Genetika Traveling Salesman Problem 
with Time Window: Studi Kasus Rute Antar Jemput Laundry”. Universitas Brawijaya.

[8] Ulfah, Nur dkk. 2014. "Sikap Kerja dan Risiko Musculoskeletal Disorderspada Pekerja Laundry”.Universitas Soedirman

[9] Kamil, H., \& Duhani, A. (2016). Pembangunan Sistem Informasi Pelayanan Jasa Laundry Berbasis Web Dengan Fitur Mobile Pada 21 Laundry Padang. Prosiding Semnastek.

[10] Akbar R \& Kamil H. 2017. "Development Of Sales Application Of Prepaid Electricity Voucher Based On Android Platform Using Quick Response Code (Qr Code)". Jurnal Informatika Vol. 11, No. 2 Juli 2017

[11] Kamil, H. (2013) “Pengembangan Aplikasi Distribusi Surat Di Fakultas Teknologi Informasi Dengan Notifikasi Sms Menggunakan Framework Yii Dan Gammu”, Jnte, 2(2), pp. $39-45$.

[12] Yu, H. R. (2015) "Design and implementation of web based on Laravel framework", Atlantis Press, (Iccset 2014), pp. 301304.

[13] Fahrudin, A. (2011) "Pembangunan Sistem Informasi Layanan Haji Berbasis Web Pada Kelompok Bimbingan Ibadah Haji", Speed, 9330(1), pp. 63-71.

[14] Handayani, S. P. M. Purnama, B. E. (2013) Pembuatan Website E-Commerce Pada Distro Java Trend, Seminar Riset Unggulan Nasional Informatika Dan Komputer FTI UNSA ISSN: 2302-1136, Volume 2, pp. 18-24.

[15] Irmansyah F. (2003) Pengantar Database. Ilmukomputer.com:Kuliah Umum IlmuKomputer.com.

[16] Bespriadi A, Hasan A, Akbar R .2015. Pembangunan Aplikasi E-Ticketing Menggunakan Teknologi QR Code Berbasis Web dan Akses Mobile Pada BRT Trans Padang, Seminar Nasional Teknologi Informasi UNTAR, p. 55.

[17] Haryani. 2015. "Pemanfaatan Web Sistem Informasi Akademik Sebagai Pengontrol Nilai Siswa (Studi Kasus) MTS Pondok Modern Al-Islam Nganjuk”. 27(2). pp.52-53.

[18] Sommerville. 2011. Software Engineering Ninth Edition, Boston: Person Education 